\title{
Survey Design for Determining Tourist's Travel Destination Choice
}

\author{
Noorezatty Mohd Yusop, Sarah Ahmad Razlah, Anesha Humaira Abu \\ Hasan, Haleesya Abu Bakar
}

To Link this Article: http://dx.doi.org/10.6007/IJARBSS/v11-i9/10872

DOI:10.6007/IJARBSS/v11-i9/10872

Received: 19 July 2021, Revised: 21 August 2021, Accepted: 02 September 2021

Published Online: 20 September 2021

In-Text Citation: (Yusop et al., 2021)

To Cite this Article: Yusop, N. M., Razlah, S. A., Hasan, A. H. A., \& Bakar, H. A. (2021). Survey Design for Determining Tourist's Travel Destination Choice. International Journal of Academic Research in Business and Social Sciences, 11(9), 1016-1024.

\section{Copyright: (c) 2021 The Author(s)}

Published by Human Resource Management Academic Research Society (www.hrmars.com)

This article is published under the Creative Commons Attribution (CC BY 4.0) license. Anyone may reproduce, distribute, translate and create derivative works of this article (for both commercial and non-commercial purposes), subject to full attribution to the original publication and authors. The full terms of this license may be seen

at: http://creativecommons.org/licences/by/4.0/legalcode

Vol. 11, No. 9, 2021, Pg. 1016 - 1024

Full Terms \& Conditions of access and use can be found at http://hrmars.com/index.php/pages/detail/publication-ethics 


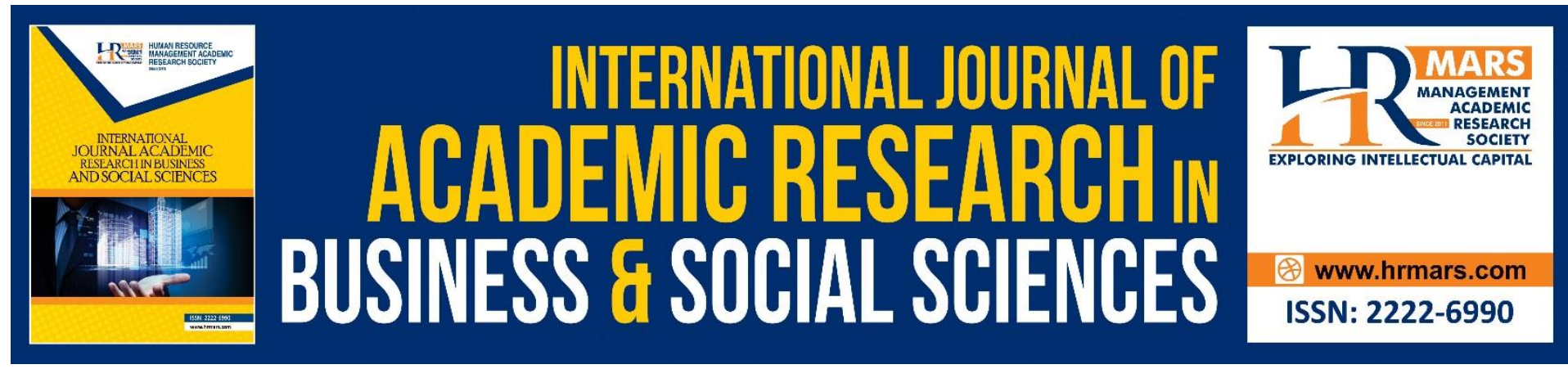

\title{
Survey Design for Determining Tourist's Travel Destination Choice
}

\author{
Noorezatty Mohd Yusop, Sarah Ahmad Razlah, Anesha \\ Humaira Abu Hasan, Haleesya Abu Bakar
}

Faculty of Computer and Mathematical Sciences, Universiti Teknologi MARA, Negeri Sembilan Branch, Seremban Campus, Seremban, 70300 Negeri Sembilan, MALAYSIA Email: noorezatty@uitm.edu.my

\begin{abstract}
The tourism industry plays an important role in the economic growth of countries all around the world including Malaysia. Thus, identifying tourist most preferred travel destination based on a set of travel criteria assist in the strategy of marketing and promoting a travel destination. The objective of this paper is to propose a survey design to determine the most important travel criteria for selecting travel destinations in the state of Perak, Malaysia. The Analytical Hierarchy Process (AHP) was employed and the decision problem was structured into a threelevel hierarchy consists of the goal, travel criteria and travel alternatives. The study had identified three travel destinations namely Ipoh, Kuala Kangsar and Pulau Pangkor and four travel criteria; beauty, cost, transportation and accommodation. Respondents consist of tourists of Perak were required to answer a set of questionnaires to provide pairwise comparison scores of travel criteria and travel destinations based on $1-9$ scale. This paper shares strategy in travel's choice problem formulation and questionnaire design.
\end{abstract}

Keywords: Analytical Hierarchy Process, Multi-criteria Decision Making, Tourism, Travel Choice, Destination Choice

\section{Introduction}

Understanding domestic tourists' preferences on destination choice can be a key factor in tourism authorities and travel agencies planning, especially when it comes to deciding each tourism destination's marketing strategies. However, the selection of tourist's most preferred destination is complicated and involves a multi-criteria process (Roy et al., 2019). Thus, tourist's decision-making had always been a concern. Malaysia is a country with many states consisting of many points of interest and the interest of this study is to determine the factors that are important in attracting tourists to a specific travel destination.

Underlying reasons for tourists to select a destination are derived from multiple different factors or criteria. Diverse contributing factors result in a more complex decision-making process. The level of importance of travel criteria and travel choice could be done through the ranking process. The process helps to determine tourist travel destinations and factors 
affecting the choice, alarming tourism management their strengths and weaknesses. The results may help them to expand and grow the potential of Perak in the tourism industry.

Problem of tourism destination selection or destination choice can be categorized as AHP problem (Genç \& Filipe, 2016). The Analytical Hierarchy Process (AHP) originally introduced by Saaty (1977 \& 1980) is a procedure for organizing and analyzing multi-criteria decisions. AHP has a specific application in complex decision-making and is used in an extensive variety of decision-making situations in various fields (Rezaeisabzevar et al., 2020). The process in AHP involved developing a numerical score to rank each decision based on how well the alternative meets the criteria of the decision maker. The method can assist decision makers in evaluating a finite set of alternatives to choose the best option, rank options according to level of importance, and classify options into predefined groups (Kolios et al., 2016). Studies had shown that the method was applied to solve the issue of making choices for an individual or a group.

\section{Objectives of the paper:}

i. To determine the factors in attracting tourists to a specific travel destination.

ii. To develop a survey design in identifying the most important criterion for selecting travel destinations in the state of Perak, Malaysia.

\section{Travel Criteria of Travel Choice}

Traveling helps us to meet people from various cultures, each with their own customs and ways of life. Some people, on the other hand, travel for particular purposes. Destination choice has always been an important aspect of tourism literature and many criteria or factors influencing travel decisions.

Accommodation is essential in the tourism industry since it is one of the most important aspects of the tourism supply chain and has an effect on tourist satisfaction (Silaban et al., 2019). Accommodation is a place to stay that caters to the needs of visitors on a daily basis and at any given time. This will be much needed for tourists who require a place to rest and revive during their travel (Giampiccoli \& Saayman, 2018). Types of traveller and purposes affect tourists' preferences in selecting a place to stay. For the hotel industry, their five main customers are business, couples, families, friends and solo (Banerjee \& Chua, 2016). On the other hand, hotels, relatives' and friends' homes, second homes, and tourist apartments are among the most common choices for senior tourists (Losada et al., 2017). Thus, providing a variety of accommodation facilities gives more choices to tourists.

Alongside, transportation is also an important aspect of the tourism industry and connects tourists to various tourist attractions. Part of each trip is the transportation and transportation system. The tourists' experience and overall satisfaction are influenced by the availability and quality of transportation at the destination (Virkar \& Mallya, 2018). Transport enables the tourists to move between their place of origin and their destination that allows maximum exposure of visitor flows to their destinations. According to previous studies, there is a positive relationship between road infrastructure and tourist activities, which will grow the tourism industry (Zhang et al., 2019). For example, in Japan and China, the creation of bullet trains has greatly increased tourism because fast public transportation has made it easier for people to reach tourist destinations. Meanwhile, ride-hailing service Uber plays a 
significant role in stimulating the tourism economy in Sub-Saharan African countries (Park et al., 2020). Therefore, understanding how visitors use the transportation system is critical to improve the destination's competitiveness.

In selecting a tourism destination, travellers based their decisions on the perception of the image attributes and the attractiveness of the natural beauty of the travel destination obtained from several sources of information. Beaches, tropical island resorts, national parks, mountains and forests, are traditional attractions because of their natural beauty (Zhang et al., 2019). Tourists may choose to take detours to see those places and take in the sights, even if they are far away (Zhong et al., 2019). Some tourists value beauty differently. Someone who loves the environment may choose to travel to a national park or a coral island while someone who appreciates local heritage may choose places such as monuments, canals, post-war sites, and museums to gain more understanding about the places (Coningham \& Lewer, 2019). Normally, tourists valued the uniqueness of the scenery and atmosphere in their photographs and on social media (Huertas \& Marine-Roig, 2016).

Tourists select their destinations based on the cost of travel. Therefore, the estimated cost can be calculated based on the trips performed by tourists. If the tourists have a small budget, they will select a spot that is close to their home to save money on transportation (Caisar Darma et al., 2020). They would use some of their earnings for other expenses including transportation, food, accommodation, shopping, and other necessities while on vacation. Besides that, the level of income affects the willingness to spend and decision of travel location. The desire to travel increases as one's income rises (Jebb et al., 2018). Higher income tourists are willing to travel far from home or pay high transportation costs. The following table presents the travel criteria that influence tourists' travel destinations.

\begin{tabular}{ll}
$\begin{array}{l}\text { Table 1: Criteria of Travel Destination Choice } \\
\text { Travel Criteria }\end{array}$ & Description \\
\hline Accommodation & $\begin{array}{l}\text { Different types of accommodation available } \\
\text { for different tourist's preferences }\end{array}$ \\
\hline Beauty & $\begin{array}{l}\text { Destination that holds beauty in landscape } \\
\text { and environment that captivates tourists }\end{array}$ \\
\hline Transport & $\begin{array}{l}\text { Availability of any mode of transportation } \\
\text { for the convenience of tourists }\end{array}$ \\
\hline Cost & $\begin{array}{l}\text { Destination with adaptable budget ranges } \\
\text { for tourists }\end{array}$ \\
\hline
\end{tabular}

\section{Methodology}

This research was organized in two phases. In the first phase, the problem was formulated as a multi criteria decision making problem and involved the process of identifying the goal, decision criteria, decision alternatives and designing the questionnaires. The second phase involved the use of the instrumentation on a set of participants to generate results, conclusions and recommendations for the study. This paper discusses the process of problem formulation and the design of questionnaires thoroughly. 


\section{Problem Definition and Goal}

The objective is to determine the priority of travel criteria for selecting travel destinations in Perak. Points of interest in Perak were categorized and this paper proposed three travel destinations namely Ipoh, Kuala Kangsar and Pulau Pangkor.

Table 2: Choice of Alternatives

\begin{tabular}{l|l}
\hline Travel Destinations & Points of Interest \\
\hline Ipoh & $\begin{array}{l}\text { Concubine Lane, Mural Art Trail, Café } \\
\text { Hopping, Museums, Monuments }\end{array}$ \\
\hline Pulau Pangkor & $\begin{array}{l}\text { Pangkor Hill Hiking, Island Hopping, } \\
\text { Water Activities }\end{array}$ \\
\hline \multirow{3}{*}{ Kuala Kangsar } & $\begin{array}{l}\text { Muzium Diraja Kuala Kangsar, Tekat } \\
\text { Emas Weaving, Labu Sayong } \\
\text { Craftsmanship }\end{array}$ \\
\hline
\end{tabular}

\section{AHP Hierarchy Structure}

Based on Figure 1, the objective or goal is positioned on the top level of the hierarchy. The problem is to select the most preferred travel destination in Perak by tourists. The selection is to be made from a set of alternatives which are Ipoh, Kuala Kangsar, and Pulau Pangkor at the lowest level of the hierarchy. The selection is based on criteria in the second level of hierarchy namely beauty, accommodation, transportation and cost. Through a synthesis process in analysis, a destination with the highest total rating will be recommended.

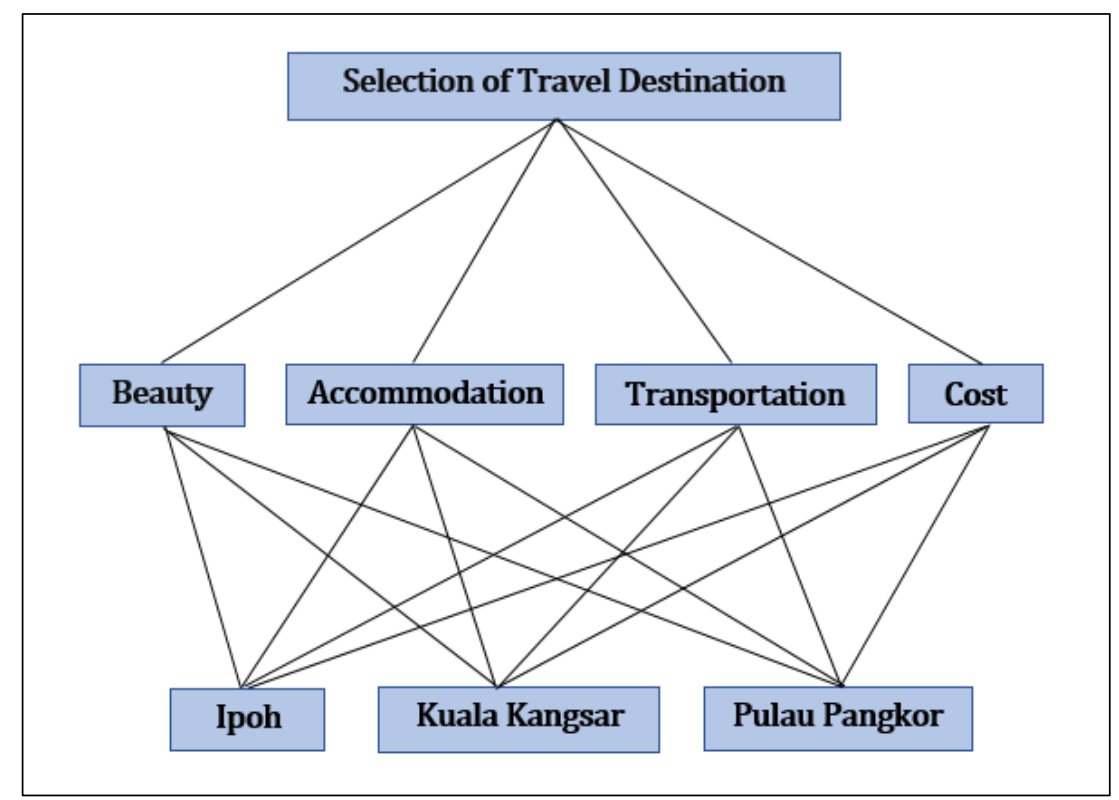

Figure 1: AHP Hierarchy for Selecting Travel Destination

\section{Designing the Questionnaires}

The determination of priority or weights for the elements (decision criteria or decision alternatives) will be done through pairwise comparison of the elements. The technique proposed by Saaty (1980) was applied when comparing two elements. However, more advanced procedures involving fuzzy triangular numbers were frequently employed to infer 
values to linguistic variables. Scales used in AHP questionnaire ranges from value 1 to 9 as stated in Table 3.

Table 3: AHP Preference Scale

\begin{tabular}{ll}
\hline Preference Level & Numeric Value \\
\hline Equally Preferred & 1 \\
Equally to Moderately Preferred & 2 \\
Moderately Preferred & 3 \\
Moderately to Strongly Preferred & 4 \\
Strongly Preferred & 5 \\
Strongly to Very Strongly Preferred & 6 \\
Very Strongly Preferred & 7 \\
Very Strongly to Extremely Preferred & 8 \\
Extremely Preferred & 9 \\
\hline
\end{tabular}

In the Analytical Hierarchy Process, comparisons are to be made between travel criteria and also between travel destinations with respect to specific travel criteria. While comparing travel criteria with $n$ elements, there are $n(n-1) / 2$ judgments required to develop the set of matrices. In Table 4, pair-wise comparison between four travel criteria have made up six judgments. Pairwise comparison between elements was obtained from values assigned by respondent using AHP scale.

The values assigned in questionnaire will be transformed into pairwise comparison matrix ranges from $1 / 9$ to 9 , where the reciprocals $1 / 9$ would imply that the one element is extremely less important than the other, and 9 implies that the element is extremely more important than the other. A case of equal importance is indicated by the value 1 .

The following tables are samples of questionnaires for the respondent to make their choice based on their judgement.

Table 4: Compare each of the following pairs of travel criteria in visiting Perak, which is more preferred?

\begin{tabular}{|c|c|c|c|c|c|c|c|c|c|c|c|c|c|c|c|c|c|c|}
\hline \multirow{2}{*}{$\begin{array}{l}\text { Travel } \\
\text { Criteria } \\
\text { Beauty }\end{array}$} & \multicolumn{17}{|c|}{ Numerical Scale } & \multirow{2}{*}{$\begin{array}{l}\text { Travel Criteria } \\
\text { Transport }\end{array}$} \\
\hline & 9 & 8 & 7 & 6 & 5 & 4 & 3 & 2 & 1 & 2 & 3 & 4 & 5 & 6 & 7 & 8 & 9 & \\
\hline Beauty & 9 & 8 & 7 & 6 & 5 & 4 & 3 & 2 & 1 & 2 & 3 & 4 & 5 & 6 & 7 & 8 & 9 & Cost \\
\hline Beauty & 9 & 8 & 7 & 6 & 5 & 4 & 3 & 2 & 1 & 2 & 3 & 4 & 5 & 6 & 7 & 8 & 9 & $\begin{array}{l}\text { Accommodatio } \\
\mathrm{n}\end{array}$ \\
\hline Transport & 9 & 8 & 7 & 6 & 5 & 4 & 3 & 2 & 1 & 2 & 3 & 4 & 5 & 6 & 7 & 8 & 9 & Cost \\
\hline Transport & 9 & 8 & 7 & 6 & 5 & 4 & 3 & 2 & 1 & 2 & 3 & 4 & 5 & 6 & 7 & 8 & 9 & $\begin{array}{l}\text { Accommodatio } \\
\mathrm{n}\end{array}$ \\
\hline Cost & 9 & 8 & 7 & 6 & 5 & 4 & 3 & 2 & 1 & 2 & 3 & 4 & 5 & 6 & 7 & 8 & 9 & $\begin{array}{l}\text { Accommodatio } \\
\mathrm{n}\end{array}$ \\
\hline
\end{tabular}


Table 5: How would you rate the travel destinations with respect to beauty?

\begin{tabular}{lllllllllllllllllll}
\hline $\begin{array}{l}\text { Travel } \\
\text { Destination }\end{array}$ & \multicolumn{11}{ll}{ Numerical Scale } \\
\hline Ipoh & 9 & 8 & 7 & 6 & 5 & 4 & 3 & 2 & 1 & 2 & 3 & 4 & 5 & 6 & 7 & 8 & 9 & Kuala Kangsar \\
Ipoh & 9 & 8 & 7 & 6 & 5 & 4 & 3 & 2 & 1 & 2 & 3 & 4 & 5 & 6 & 7 & 8 & 9 & Pulau Pangkor \\
Pulau Pangkor & 9 & 8 & 7 & 6 & 5 & 4 & 3 & 2 & 1 & 2 & 3 & 4 & 5 & 6 & 7 & 8 & 9 & Kuala Kangsar \\
\hline
\end{tabular}

Table 6: How would you rate the travel destinations with respect to transport?

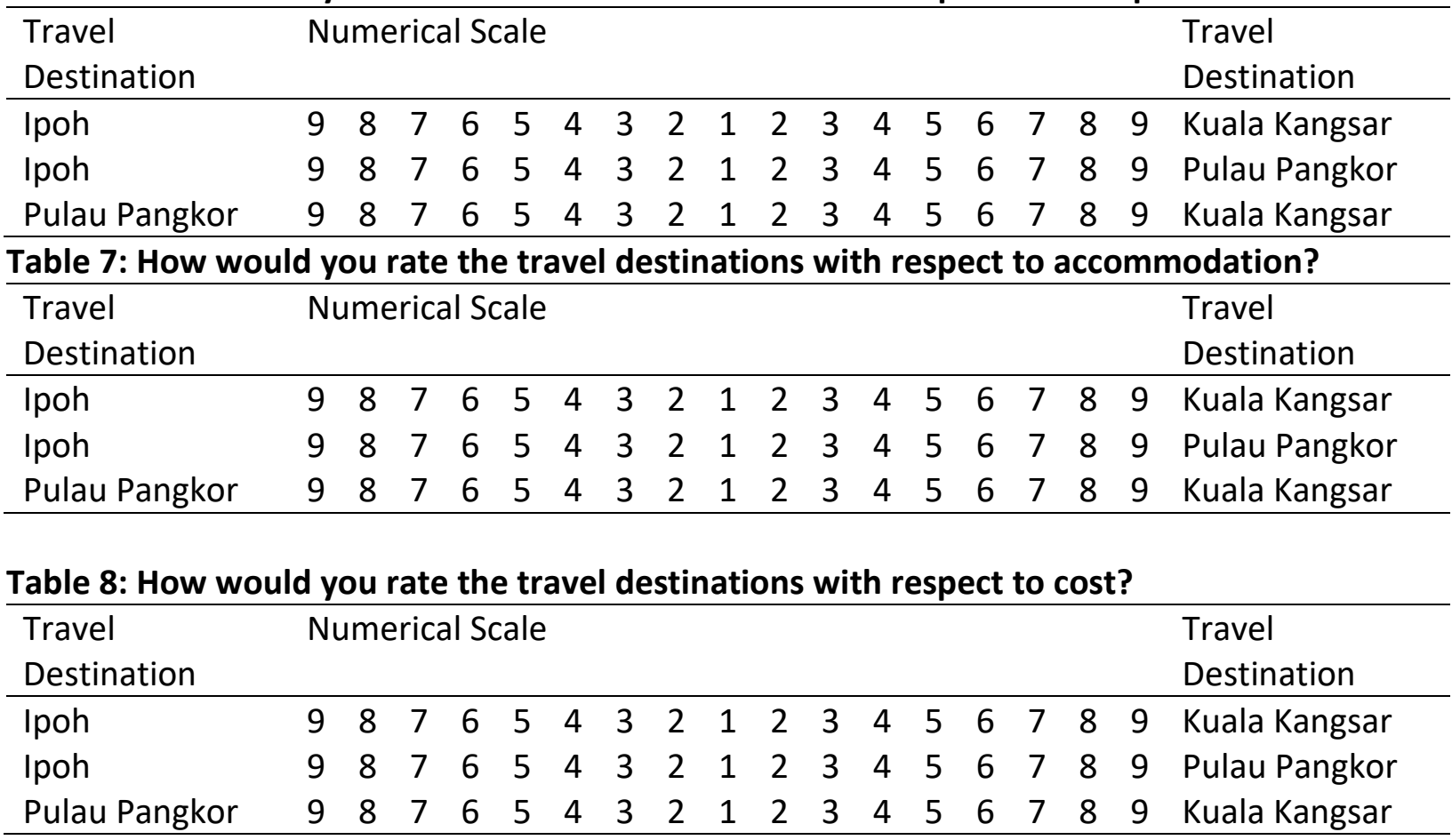

\section{Data Analysis Tool}

Expert Choice software is Collaborative Decision Making tool that aids intuition research. It is a graphical-based structure that can apply judgement to objectives which in the end, produces the desired outcome. The benefit of adopting this software is that it does not only assist decision makers in making the best choice, but also provides a clear picture of that choice. This is true since the given results provide extra internal validity through visual integration in testing the sensitivity analysis.

Decision makers can use the AHP and Expert Choice software to break down a decisionmaking process into smaller parts. Starting with a specific goal, then moving on to objectives, sub-objectives, and finally the alternatives. To get at the overall priorities for the alternatives, basic pair-wise comparison judgement was applied throughout the process.

\section{Conclusion}

This study attempted to determine the travel criteria for selecting most preferred travel destinations in Perak. The points of interest in Perak were grouped into three destinations; Ipoh, the capital city of Perak, Pulau Pangkor, the jewel of Perak's nature enthusiasts and Kuala Kangsar, the royal capital of Perak. As for the criteria in this research, four main criteria were selected namely beauty, transport, cost, and accommodation. A set of questionnaire was designed to capture respondent's judgement. The results from the questionnaires will assist the following process in Analytical Hierarchy Process. 


\section{References}

Banerjee, S., \& Chua, A. Y. (2016). In search of patterns among travellers' hotel ratings in TripAdvisor. Tourism Management, 53, 125-131. https://doi.org/10.1016/j.tourman.2015.09.020

Darma, C. D., Maria, S., Kasuma, J., \& Lestari, D. (2020). Factors involved in the number of tourist visits in the Muara Badak, Indonesia. Religación. Revista De Ciencias Sociales $Y$ Humanidades, 5(24), 142-151. https://doi.org/10.46652/rgn.v5i24.623

Coningham, R., \& Lewer, N. (2019). Communities, Identities, Conflict and Appropriation in South Asia. In: Coningham R., Lewer N. (eds) Archaeology, Cultural Heritage Protection and Community Engagement in South Asia. Palgrave Pivot, Singapore. https://doi.org/10.1007/978-981-13-6237-8_11

Genç, T., \& Filipe, J. A. (2016). A fuzzy MCDM approach for choosing a tourism destination in Portugal. International Journal of Business and Systems Research, 10(1), 23. https://doi.org/10.1504/ijbsr.2016.073688

Giampiccoli, A., \& Saayman, M. (2018). Community-based tourism development model and community participation. African Journal of Hospitality, Tourism and Leisure, 7(4), 127.

Huertas, A., \& Marine-Roig, E. (2015). User reactions to destination brand contents in social media. Information Technology \& Tourism, 15(4), 291-315. https://doi.org/10.1007/s40558-015-0045-9

Jebb, A. T., Tay, L., Diener, E., \& Oishi, S. (2018). Happiness, income satiation and turning points around the world. Nature Human Behaviour, 2(1), 33-38. https://doi.org/10.1038/s41562-017-0277-0

Kolios, A., Mytilinou, V., Lozano-Minguez, E., \& Salonitis, K. (2016). A comparative study of multiple-criteria decision-making methods under stochastic inputs. Energies, 9(7), 566. https://doi.org/10.3390/en9070566

Losada, N., Alén, E., Nicolau, J. L., \& Domínguez, T. (2017). Senior tourists' accommodation choices. International Journal of Hospitality Management, 66, 24-34. https://doi.org/10.1016/j.ijhm.2017.06.014

Park, S. Y., Kim, J., \& Pan, B. (2020). The influence of uber on the tourism industry in subsaharan Africa. Journal of Travel Research, 0047287520951638. https://doi.org/10.1177/0047287520951638

Rezaeisabzevar, Y., Bazargan, A., \& Zohourian, B. (2020). Landfill site selection using multi criteria decision making: Influential factors for comparing locations. Journal of Environmental Sciences, 93, 170-184. https://doi.org/10.1016/j.jes.2020.02.030

Roy, J., Sharma, H. K., Kar, S., Zavadskas, E. K., \& Saparauskas, J. (2019). An extended COPRAS model for multi-criteria decision-making problems and its application in web-based hotel evaluation and selection. Economic Research-Ekonomska Istraživanja, 32(1), 219-253. https://doi.org/10.1080/1331677x.2018.1543054

Saaty, T. L. (1977). A scaling method for priorities in hierarchical structures. Journal of Mathematical Psychology, 15(3), 234-281. https://doi.org/10.1016/00222496(77)90033-5

Saaty, T. L. (1980). The analytic hierarchy processes. New York: McGraw-Hill.

Silaban, P. H., Pasaribu, A., \& Silalaho, A. D. K. (2019). The influence of human aspect of accommodation and destination on tourist satisfaction. International Journal of Innovative Technology and Exploring Engineering, 8(9S8), 105-108.

https://doi.org/10.35940/ijitee.i1021.0789s219 
Virkar, A. R., \& Mallya, P. D. (2018). A review of dimensions of tourism transport affecting tourist satisfaction. Indian Journal of Commerce \& Management Studies, 9(1), 72-80. https://doi.org/10.18843/ijcms/v9i1/10

Zhang, Y., Khan, S. A. R., Kumar, A., Golpîra, H., \& Sharif, A. (2019). Is tourism really affected by logistical operations and environmental degradation? An empirical study from the perspective of Thailand. Journal of Cleaner Production, 227, 158-166. https://doi.org/10.1016/j.jclepro.2019.04.164

Zhong, L., Sun, S., \& Law, R. (2019). Movement patterns of tourists. Tourism Management, 75, 318-322. https://doi.org/10.1016/j.tourman.2019.05.015 